University for Business and Technology in Kosovo

UBT Knowledge Center

Nov 7th, 3:15 PM - 3:30 PM

\title{
The impact of the financial crises in the management of the corporates
}

Armanda Keqi

Epoka University, akeqi@epoka.edu.al

Ilda Topalli

Epoka University, itopalli11@epoka.edu.al

Follow this and additional works at: https://knowledgecenter.ubt-uni.net/conference

Part of the Business Commons

\section{Recommended Citation}

Keqi, Armanda and Topalli, Ilda, "The impact of the financial crises in the management of the corporates" (2014). UBT International Conference. 33.

https://knowledgecenter.ubt-uni.net/conference/2014/all-events/33

This Event is brought to you for free and open access by the Publication and Journals at UBT Knowledge Center. It has been accepted for inclusion in UBT International Conference by an authorized administrator of UBT Knowledge Center. For more information, please contact knowledge.center@ubt-uni.net. 


\title{
The impact of the financial crises in the management of the corporates
}

\author{
Armanda Keqi ${ }^{1}$, Ilda Topalli \\ ${ }^{1,2}$ Epoka University \\ Banking \& Finance Department, Tirana, Albania \\ akeqi@epoka.edu.al ${ }^{1}$,itopalli11@epoka.edu.al ${ }^{2}$
}

\begin{abstract}
Financial crises are very damaging and costly. They can spread easily from one country to another. The most apparent example was the crisis of 2008, which took global dimensions. The entire world was affected by the crisis and many countries are still suffering the consequences, such as: economic decline, failure of banks or financial institutions, price fluctuations, etc. The main factors that cause shocks in the financial sector can be grouped as follows: inappropriate macroeconomic policies, the weakness of the financial system, global financial conditions, the difference of exchange rates and political instability. These factors, create the conditions for the crisis to occur, and precisely these factors will be the theme element of our study. This study, which analyzes the elements that changed corporate governance after the crisis of 2008, will also focus on the impact that these structural changes had in the level of job satisfaction of employees, given the extent of the layer, that represent people who have suffered the most severe economic shock of this crisis. The collected data of the employees of a company in Albania was analyzed through the T-test, which aims to compare how elements of job satisfaction vary from one period to another, and how statistically the differences are significant. The salary and the level of commitment were associated with the level of satisfaction of the employees during the economic crisis of 2008, and then compared with the period after, through the Chi- square test, to verify the presence of a correlation between them.
\end{abstract}

Keywords: financial crisis, corporate, work satisfaction, employee

\section{Introduction}

The principles of a good corporate governance have been the most important components of the international financial standards and they've been seen as essential to the stability and integrity of the financial systems. Over the last 10 years, a lot of energy and attention have been devoted to the improvement of skills boards, managers and owners, in order to improve market conditions.

Many of the problems in the years 2007-2008 are explained with the shortcomings in the implementation of good principles and driven by the behavior towards short-term benefits. Corporate governance refers to a set of rules through which the company is directed and controlled. It identifies and defines the rights and responsibilities between managers, board of directors, shareholders and provides the structure for the establishment, implementation and the monitoring of the company objectives. A company committed to a good governance owns a board empowered, internal control consolidated, high levels of transparence rights and it should be capable to increase human development. However there are arguments that cast doubt on the ability of corporations to achieve the goals mentioned above. Joel Baka has defined the corporation as "an pathological institution, a dangerous possessor of power that is exercised over people and society". This sounds somewhat like an exaggerated citation, but what he wanted to describe Baka is the fact that the interest of the corporation may often have consequences for society, consequences that corporations do not worry about.

The economic behavior theory has consistently emphasized the distinctiveness of the corporation as a developed organizational entity but also has divided the forms of governance. The crises have always shaped the legislation and lastly also the companies corporations codes. Over time corporations are responding to these changes, to industrialism and market growth as well as to the functional business needs. All these have played an important role in shaping the corporate governance after the economic crisis. Friedman argues that a model should be judged by its predictive power respectively to the phenomena that aims to explain. The shareholders, who are the "owners" of the companies, virtually have no power to control the daily operations or long-term policies. In their place, the controls are made by the boards of directors and managers, the capital of which is often small. Friedman is convinced that the separation of the ownership from the control is the only way to govern the American public corporations. The years 2008-2009 of the financial crisis 
highlighted the faults within the corporate governance. Increasing influence of shareholder interest rate on corporate practices worsened. Also the asset price bubbles during the years 1990-2000 increased the fragility of the financial sector.

The beginners of the financial crisis certainly, are the banks and mainly, responsibility their controllers (Central Banks). De Gauwe rejects the argument that even if the central banks may reveal a bubble, they are powerless to do something about it. He notes that it is naturally easier to stop "a bubble assets" rather than to tackle inflation. Central banks and supervisory authorities in order to stable liquidity, measure each banking institution (and any non-banking institution) under their jurisdiction. Contractions in the global economy manifested as a major distortion in the labor market, were forms of rising unemployment and vulnerable employment rates as well as the enlargement of the social gaps in employment in most countries that were hit by the global financial crisis. According to a report by Suleyman YAZIR, for the European Council he argues that:

Firstly, based on the estimates of ILO (International Labor Organization), the number of unemployed in the world has grown nearly 34 million between 2007 and 2009, placing the global rate of unemployment at 6.6\%. Although, emerging economies and developing countries are hit regardless of the financial crisis in terms of loss of jobs, the impact of the crisis is mainly felt in sectors strongly linked with the global economy as export and / or tourism sectors.

Secondly, this has resulted in a vulnerable employment growth and the number of "the weakest working" is about 111 million. Between the years 2008 and 2009, the unregistered number of employees has been increased considerably.

Thirdly, it has caused gaps in the labor market. Women employed in the export sector have been hit hard by finding themselves or in the informal sector or completely unemployed. In fact, the total number of unemployed women worldwide has increased nearly 15 million between 2007 and 2009. Similarly, youth unemployment (unemployment of those within the age group 16-24), also increased from 11.8\% in 2007 to $13.4 \%$ in 2009, an increase of more than 10 million. And of course those who have preserved places of work had a decline in moral and finding elements that create pleasure in job. Through our survey we will be able to draw a conclusion about these elements.

\section{The impact of financial crises in the governance of Albanian corporations}

On $28^{\text {th }}$ of July 2008 the Executive board of International Monetary Fund (IMF) announced the 5 year observation of Albanian economy performance and financial securities. The performance of Albanian economy remains strong despite the international financial conditions. Even though, Albania suffered from the regional crises in 2007 its recovery was fast owing to the development of new and diverse export markets. By doing so, the exports of goods and services have increased the economic indicator GDP (Gross Domestic Product), and Albania continuous to attract investments in its traditional exports, textile and shoes. The improvements made in taxation system have strengthen the Public Finances which has had a direct positive influence in the country's GDP. Furthermore, by implementing strict monetary policy Albania has maintained positive interest figures. Banking sector is another crucial part for which regulatory and supervision resources should give a considerable attention. Although, the banking system was exposed to the global financial crises, overall it is sound.

\subsection{The impact of financial crises on the banking sector in Albania}

Banking system in Albania had a significant success in the year of 2007. During this period there were radical developments in almost every parameter of this sector, specifically, deposits of the individuals increased by $27 \%$ more. Statistics show that, credit to economy as an important indicator reached the level of 2.4 billion euro or $30 \%$ of GDP, and loan to the individuals amplified up to $66 \%$ compare to 2006, marking a $35 \%$ of the total lending portfolio of the banking system. In 2008 there is another period of growth. Deposits kept moving upward until September reaching the level of 5.6 billion euro, and by the end of the year there was a slight decrease in deposits standing at 5.2 billion euro a $2.4 \%$ increase than the previous year. Credit to economy attained a new peak level at over 3 billion euro, or 37\% of GDP. It is worth mentioning that, this is the first full year where the Credit Registry takes place, helping the banking system make objective decisions and elude problematic clients. Moreover, banks began adjusting the system of IBAN for national and international payments. Throughout the year 2009 banking sector faced some challenges which originated from the global financial crises and from within its economic environment, yet there was a steady smooth progress. Total assets of the banks enlarged somewhere to $6.25 \%$ achieving $77.5 \%$ of national GDP. There was a raise in loans of $13.4 \%$ initiated by the banks in contrast to 2008. Nonetheless, global and regional change of macroeconomic elements had a huge influence on the banking system of Albania. There were difficulties in gathering back the money lend to individuals and businesses, specially the construction segment was the most problematic alongside with export industry, tourism, manufacturing industry and individuals. Thus, the loans were shrunk and new regulations were put in place. Now, the 
banks would lend money but with new rules where clients had to fulfil a certain criteria in order to be able to borrow money from banks. Plus, interest rates changed. The golden era when banks aggressively would attempt to attract clients through appealing offers and interest rates, ended. However, the end results for the year 2009 was still positive sitting at 3.54 billion Albanian Lek, whereas loans in rapport to deposits improved to $65 \%$ at the end of the year. The deposits from clients at the end of the year are evaluated at 694.3 billion lek an increase of only $7.6 \%$ compare to the end of 2008. In the course of this year, at the National Registration Centre (NRC) there were recorded only 13 thousand new businesses against 17 thousand during 2008. The consolidation of macroeconomic index and a moderate risk of premiums has shown a favourable business environment throughout 2010. Evidence illustrate that the economy of Albania has improved by $3.6 \%$ for the period January - September 2010, meanwhile, the annual average inflation has waved around the target of the Bank of Albania. The banking sector is dominated by 5 financial institutions which all together constitute $67.8 \%$ of the credit portfolio and $74.4 \%$ of deposits portfolio. Assets of the banking sector at the end of 2012 were estimated at $1,187.9$ billion lek with an annual growth of $6 \%$ compare to $13.1 \%$ in 2011 . With regard to financial investments resources what could be noted is that the major contribution in generating the funds comes from the depositor activity with $82.3 \%$ of the total liabilities of banking sector. Whereas, deposits from businesses shrunk by $3 \%$ against an increase of 5.7\% in 2011. On 13 $3^{\text {th }}$ of April 2014 the Minister of Economy and Development Mr. Arben Ahmetaj would state that: "the worst for the economy has ended" - according to the evaluation of Standard and Poor's for the public debt of Albania, from B- to B+.

\section{The impact of economic crises in the satisfaction of employees}

\section{What is satisfaction at work?}

The concept of satisfaction at work can be defined as the enjoyment an individual gains let that be positive or negative in relation to the daily tasks at work, salary, relationships with other colleagues, work environment and the opportunities of promotion in building up a carrier. (Kasimati \& Manxhari. 2005, p 47). Nowadays, the notion of satisfaction at work has absorbed a considerable attention integrating it alongside with the performance by implementing new methods such as rotation at work, expansion and by upgrading the surroundings of the workplace. The satisfaction at work is identified as an emotional state that one takes from the evaluation of work's duty completion.

In this emotional state is included:

$>$ The emotional reaction for the workplace

$>$ The attitude toward working position

\subsection{What are the advantages and disadvantages of having satisfied workforce?}

Commitment to the organization. Employees that have a high level of pleasure at work manifest a greater dedication for the corporation they work for.

Satisfaction and absences at work. Gratification at work is closely related to the absences of employees. The more delighted they are for the workplace the less absences there would be.

Satisfaction and turnover. Studies have shown that where dissatisfaction is concentrated in high levels, turnover is more likely to be high. Though, high satisfaction at work, in itself, does not really produce a low level of turnover.

\subsection{Economic crises and satisfaction at work}

Starting with fluctuations in financial markets, the global economic crisis reached the real economy. A number of studies have shown that the optimization of state employees for social change is relatively low. Furthermore, there is a decline in optimism about the future of the economy. The most affected people by this discouragement of optimism are those who work in the service sector followed by the sectors in construction, tourism etc. Changes undertaken through organizational restructuring certainly have had a social and psychological impact on members of 
the organization, taking into account the uncertainty that accompanies such decisions. It is of great importance to understand the potential negative consequences that can bring organizational restructuring in the workplace.

\section{Methodology}

The methodology followed in this study is a function of the whole concept of crisis, especially concentrated in one of the most delicate elements that are the second tier banks. For this reason the study is extended not only in global terms, but also in the terms of our country being associated with a more concrete example, the National Commercial Bank. We analyze the changes in the organizational structure of NCB and the impacts that the changes of the financial crisis had on the pleasure of these employees. For the realization of this study we used a job satisfaction survey (Job Satisfaction Survey, JSS; Spector, 1997; quoted in Bread, 2005) where the sample was a group of 70 employees, 41 women and 21 men, who answered confidential survey questions. More details of the survey process is given in the relevant chapter. The economic change before the financial crisis of 2008 and its aftermath has affected employee satisfaction.

The purpose of this study is to highlight the link between the changes that have occurred in the organizations / companies before and after the economic crisis and the satisfaction from the work that the employee performs.

The objective: To identify the link between economic changes before and after the crisis of 2008 and that takes employee satisfaction from work it performs, and to identify if there is a connection side of this relationship.

Institution in the study: We get to study the National Commercial Bank to which we were able to collect the necessary information to write the paper with the help and the support of the staff of this institution, so we could develop the survey that aims to measure job satisfaction. The National Commercial Bank has today naming was founded in January 1993 by the merger of the Albanian Commercial Bank and the National Bank of Albania. It was established in 1993 by a second subdivision of the State Bank of Albania for the management of commercial activity within the state entities. The National Commercial Bank was established as a joint stock company in July 1997 with a capital of 2.7 billion. NCB has a very hierarchical organizational structure, where the power lines are clearly defined. Initially in 2008, it has been an organization departmental subdivision into 8 main divisions each had. In 2012 we observed a change of organization of BKT. We noted the elimination of two important functions in the organization of the 2008 structure, there had no longer advisory board or committee and corporate governance. The IT department and the finance department are united in a single division. 
The Organizational Chart of BKT - March 2008

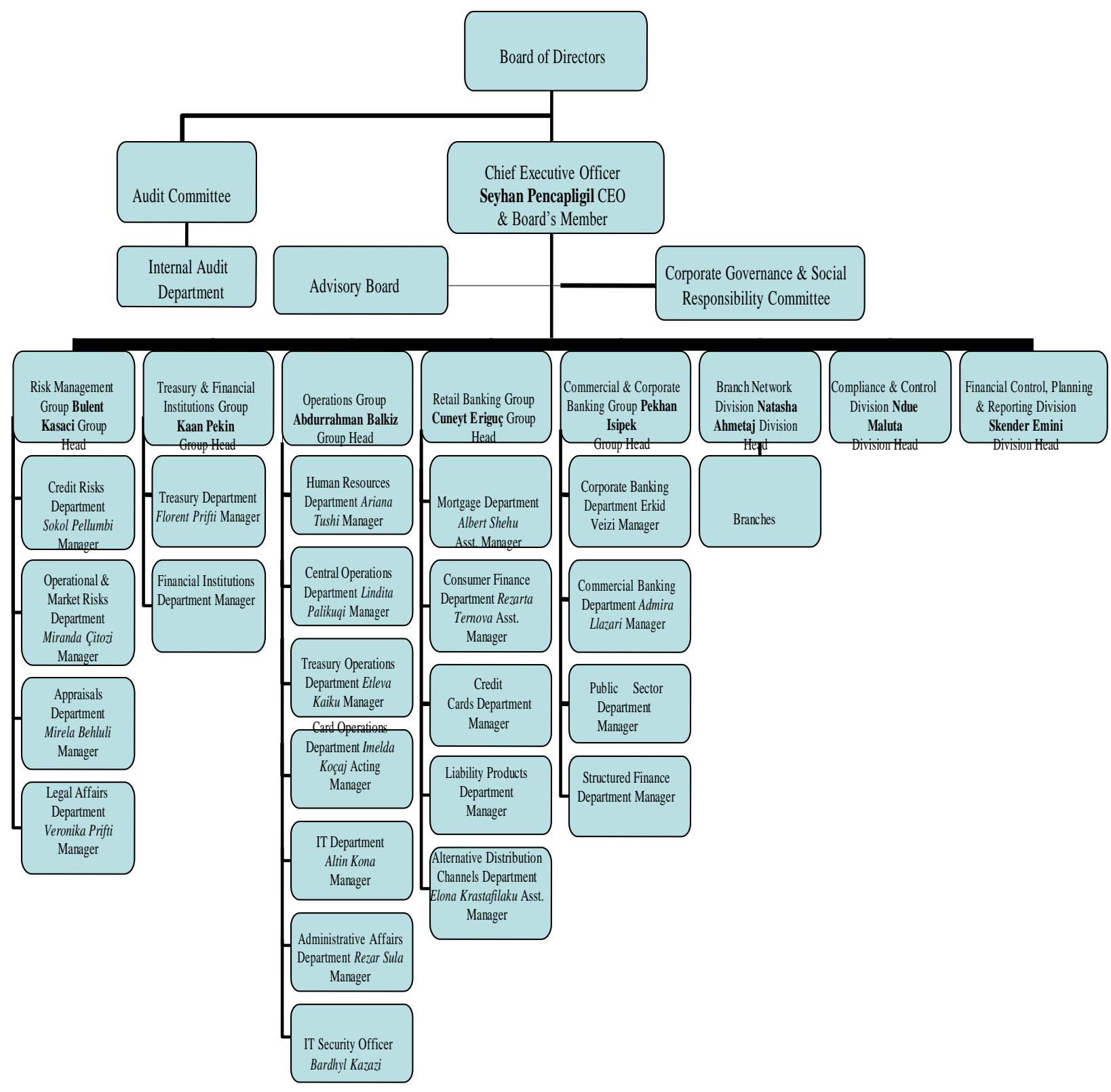

Figure 1 The organizational Chart of NCB, March 2008 
The Organizational Chart of BKT- 01 November 2012

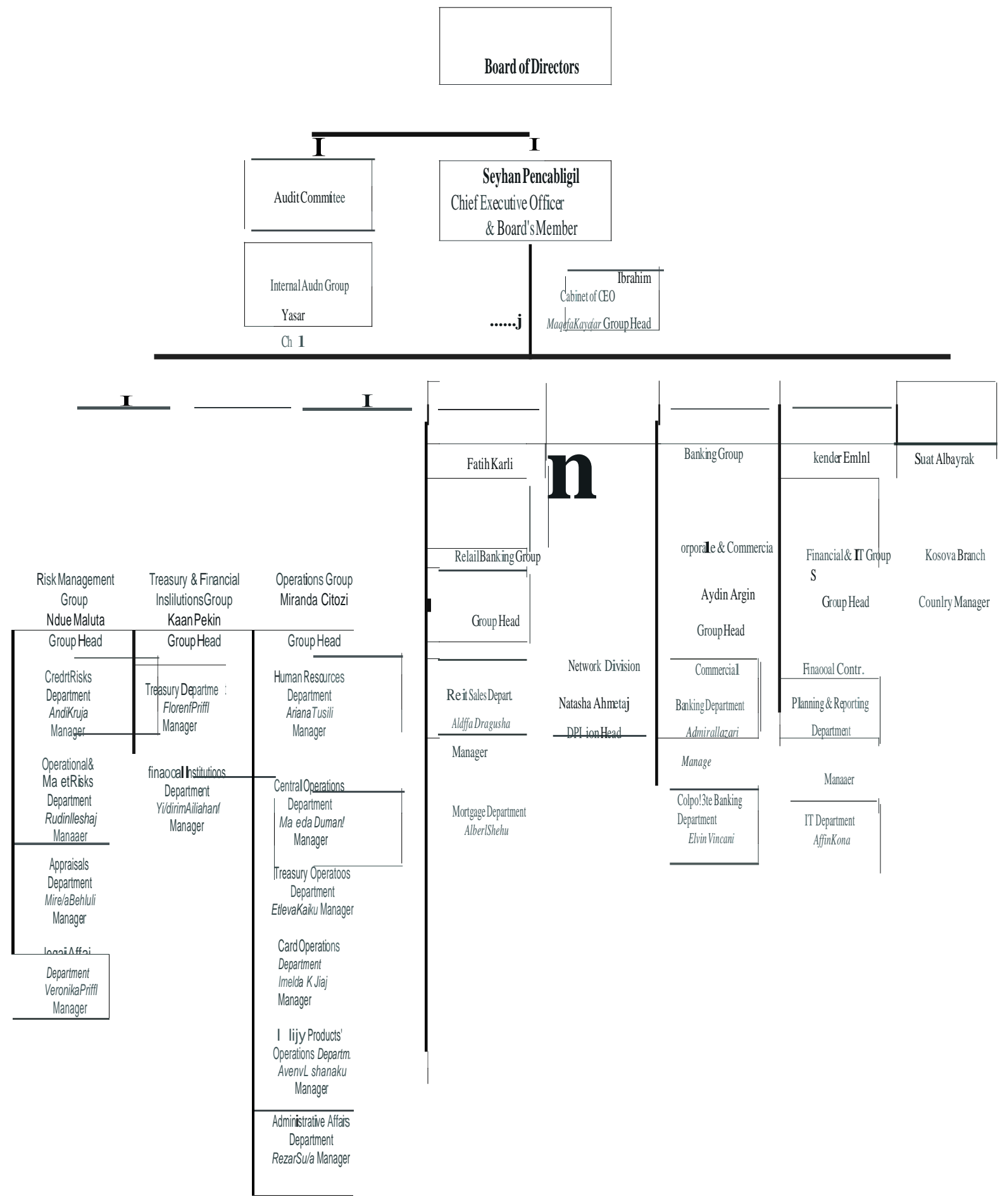




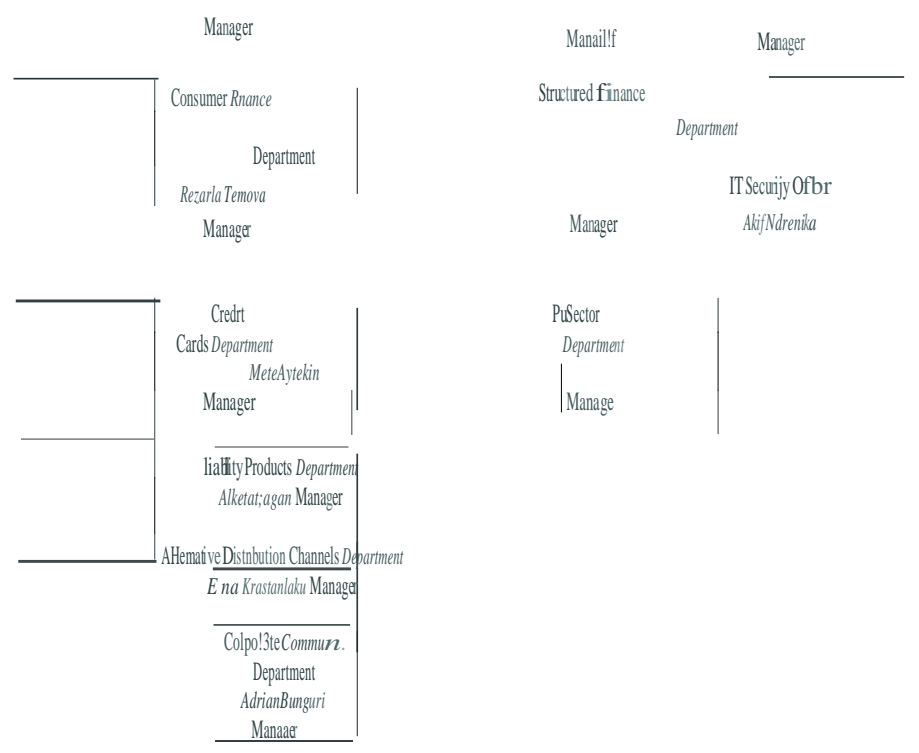

Figure 2 The organizational Chart of NCB, November 2012

\subsection{Sampling and the instrument used}

\section{The size of the sample}

The participants selected for this study were 70 employees of NCB, 41 women and 29 men, in the age from 25 to 58 years old. The average age of the sample was 27 years old. For the realization of this study, was used a job satisfaction survey (Job Satisfaction Survey, JSS; Spector, 1997; quoted in Bread, 2005). This survey was used in Albania in 2005, in different schools to measure the job satisfaction of the teachers and it was found that this instrument demonstrated validity and reliability.

\section{Procedures, validity and reliability}

To obtain more realistic results and to avoid misunderstandings before completing the survey, the participants were able to clarify any questions they may have. The time it took to fill the survey was about 10-15 minutes. This survey resulted with high validity in several studies in which it was applied. The job satisfaction survey showed a good correlation with elements of job satisfaction such as: salary, promotions, supervision, and the nature of work. The analysis of the credibility of the job satisfaction survey were conducted by McIntire \& Miller (2000, cited in Bread, 2005) according to which the Cronbach Alpha coefficient above 0.70 , is sufficient to show good reliability and validity of the instrument. As noted above this survey was used in 2005 (Bread, 2005 ) and has shown high validity $\alpha=0.89$. While in this study resulted reliability $\alpha=0.88$ level, which includes 36 statements or assertions of the instrument.4.2 Results

\section{Statistical data of the study}

Table 1 Number of employees

\begin{tabular}{|c|c|c|}
\hline & Frequency & Percentage \\
\hline NCB (female) & & \\
\hline & 4 & 58 \\
\hline
\end{tabular}




\begin{tabular}{|c|c|c|}
\hline NCB (male) & 29 & 41.4 \\
\hline Total & 7 & 100 \\
& 0 & .0 \\
\hline
\end{tabular}

Table 2 Age of participants

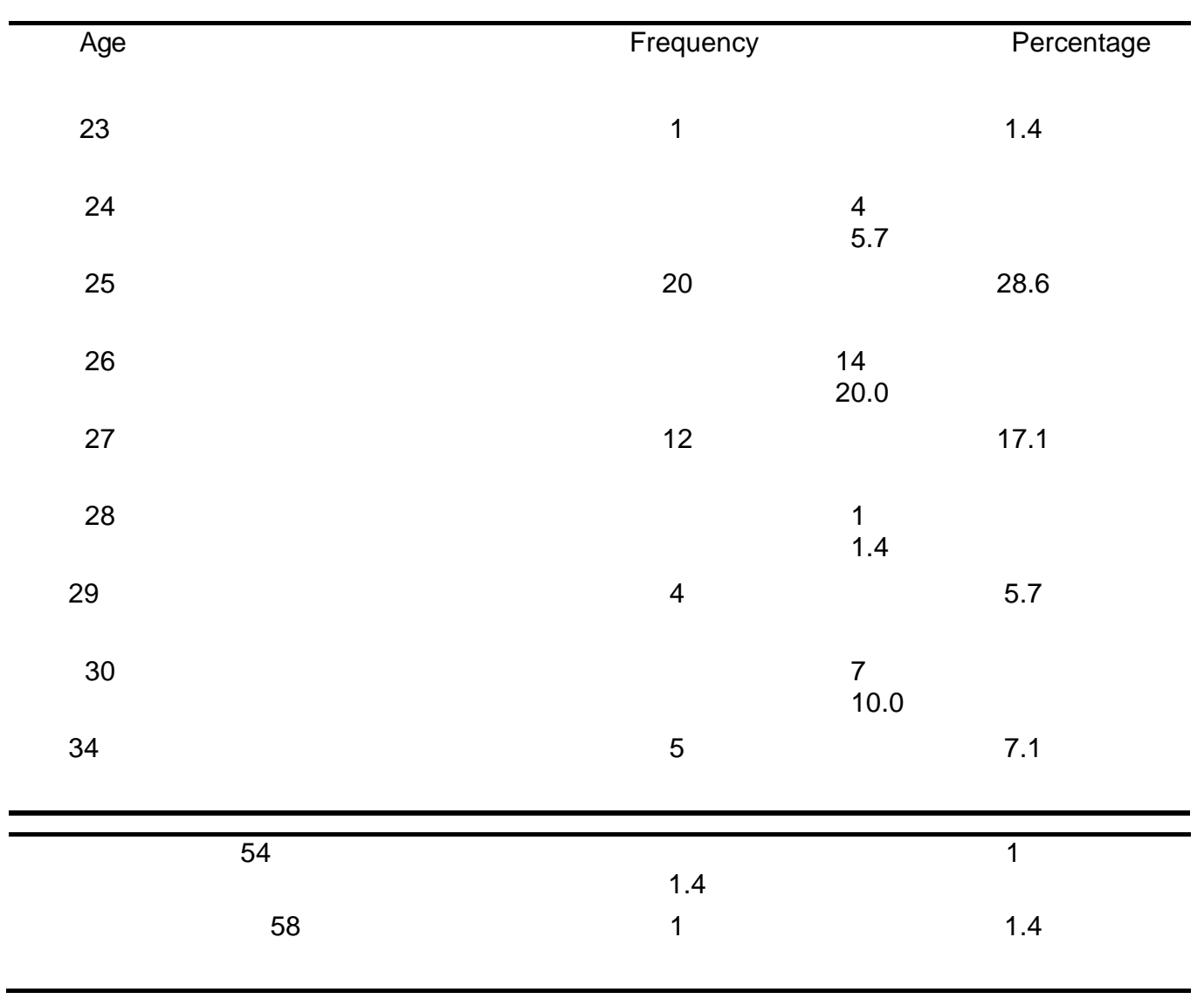

Table 3 Summarized results of the study

\begin{tabular}{|c|c|c|c|c|c|c|c|c|c|c|}
\hline Sal & & Promotion & $\begin{array}{l}\text { Relationship } \\
\text { with the } \\
\text { chief }\end{array}$ & $\begin{array}{r}\text { Extra } \\
\text { earnings }\end{array}$ & Rewards $\mathbf{R e}$ & $\begin{array}{c}\text { Relationship } \\
\text { with the } \\
\text { staff }\end{array}$ & $\begin{array}{l}\text { Type of } \\
\text { work }\end{array}$ & $\begin{array}{c}\text { Commit } \\
\text { ment }\end{array}$ & Satisfa & \\
\hline After & 4.12 & 3.95 & 4.44 & 3.15 & 3.85 & 2.92 & 4.51 & 2.99 & 4.08 & 134.3 \\
\hline \multicolumn{11}{|l|}{ crises } \\
\hline $\begin{array}{l}\text { Before } \\
\text { crises }\end{array}$ & 4.58 & 4.26 & 4.43 & 3.21 & 4.57 & 3.02 & 4.51 & 3.22 & 4.61 & 139.9 \\
\hline
\end{tabular}


As shown in the table the total number of the employees in the study received a numerical difference to the gender of the participants, in which women dominate with $58.6 \%$ and the males were $41.4 \%$.

\subsection{Analysis of T-test}

The table below shows results after analyzing the collected data through the T-test, which aims to compare how elements of job satisfaction vary from one period to another. By seeing the results, appear that the elements with statistically significant differences according to $\mathrm{T}$ - test, are the salary $(0,05)$ and the level of commitment to the company $(0,05)$. These elements associated a higher level of satisfaction to employees prior to the economic crisis in 2008 compared with the period after the 2008 crisis. Beside T-test, was conducted another test, the test Chi - square to see if there was a correlated connection between job satisfaction and economic crisis. After the analysis of the data, it was showed that this relationship was not statistically important. The correlation coefficient phi $=0.29, \mathrm{p}>0.05$. In other words, there is no statistically significant relationship between satisfaction and economic crisis after 2008.

Table 4 Results of T-test

\section{After crises}

Before crises

\begin{tabular}{|c|c|c|}
\hline Salary & & \\
\hline Average & 4.12 & 4.58 \\
\hline T-test & -1.72 & \\
\hline Sig. & 0.05 & \\
\hline Promotio & & \\
\hline Average & 4.44 & 4.43 \\
\hline T-test & -1 & \\
\hline
\end{tabular}




\begin{tabular}{|c|c|c|}
\hline Sig. & 0.31 & \\
\hline \multicolumn{3}{|c|}{ Extra earnings } \\
\hline Average & 3.15 & 3.21 \\
\hline T-test & 0.03 & \\
\hline Sig. & 0.96 & \\
\hline \multicolumn{3}{|l|}{ Rewards } \\
\hline Average & 3.85 & 4.57 \\
\hline T-test & 0.78 & \\
\hline Sig. & 0.43 & \\
\hline \multicolumn{3}{|c|}{ Conditions of work } \\
\hline Average & 2.92 & 3.02 \\
\hline T-test & -0.57 & \\
\hline Sig. & 0.56 & \\
\hline \multicolumn{3}{|c|}{ Relationship with staff } \\
\hline Average & 4.51 & 4.51 \\
\hline T-test & 0.009 & \\
\hline Sig. & 0.99 & \\
\hline \multicolumn{3}{|c|}{ Type of work } \\
\hline Average & 2.99 & 3.22 \\
\hline T-test & 0.892 & \\
\hline Sig. & 0.376 & \\
\hline
\end{tabular}




\section{Commitment}

Average

Table 5 The results of the correlation analyses

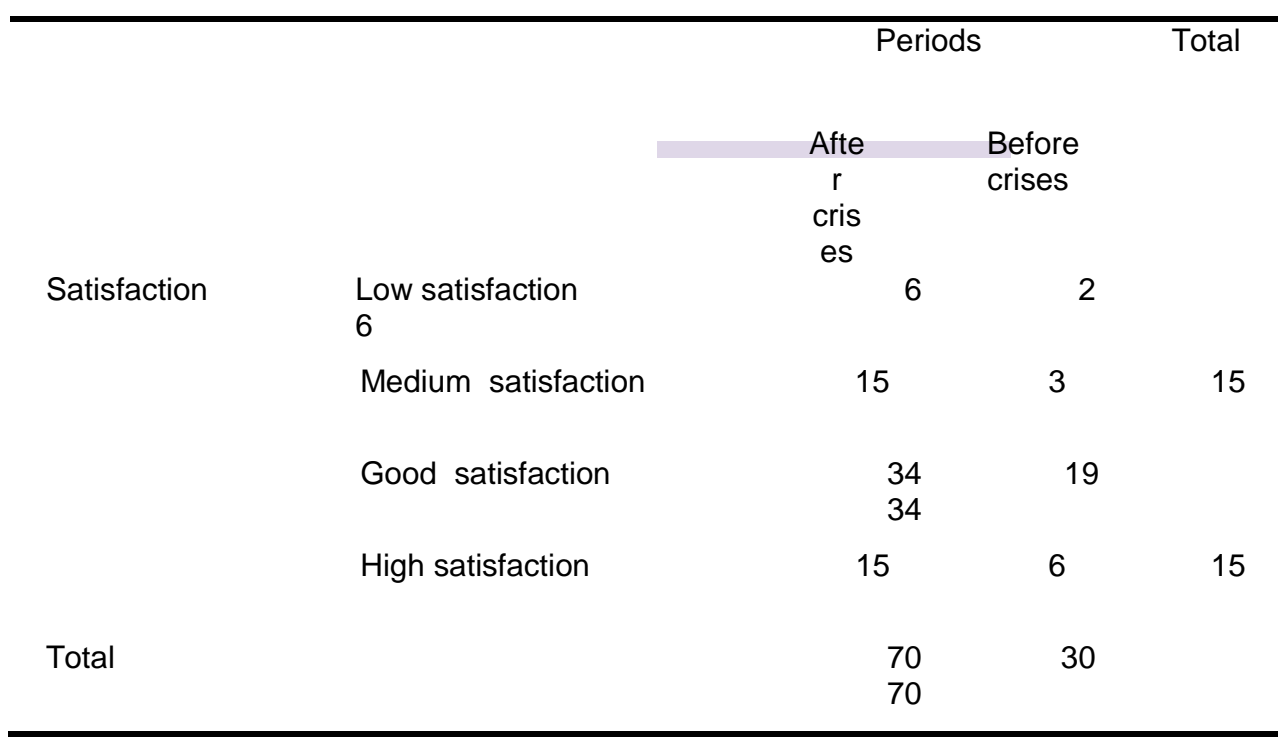

\section{Conclusions and recommendations}

Like everything else, it may happen that the systems that we use to govern our companies fail. But sometimes these failures often lead to consequences that are too large, and they can affect the entire economy. The economic crisis of 2008 indicates a failure in corporate governance practices. From every defeat, it is important to take lessons in order to prevent recurrence of the event, or to improve the practices. It's important to give an increasing importance to the higher voice of shareholders, who in their turn should be more active in the affairs of the corporation and in making their thoughts and suggestions to be considered. This naturally occurs when they themselves are aware and show interest in companies that they invest, although the number of their shares may be very small. It is also important for companies to be more transparent with shareholders and the wider public. It's important that the board members to be capable and independent. Also the reward given to the board members must not exceed the income he / she receive primarily on the work they do. Another element of risk assessment is undertaken by companies, therefore is recommended the creation of special risk departments. However there should always be kept in consideration that the values of operations of many organizations are important both for the individual and for the society of a country. To provide a quality service and to increase productivity in the organization is needed more knowledge about the best functioning possible. To ensure the good functioning is a need to arise the investing not only in materials but also in the level of skilled human resources. 
1. If the study has replications, it should expand the number of participants in the study. This will help in achieving a more reliable result and the generalization would be possible. In this way there would be the possibility to see more clearly the difference between the economic periods and to identify the relationship between the level of satisfaction in the period before the crisis and its aftermath.

2. To consider the difference between men and women. Gender of participants in the study is an important factor in the final results, because of the different mechanisms that operate in the perception of satisfaction that women and men have. Perhaps a study that would focus more on the impact of the perception of the level of job satisfaction in work of men and women would be necessary to highlight the differences if there is any.

\section{References}

1) Jones, R. G. (2004). Organizational theory, design and change. Fourth edition. McGraw Hill.

2) Buka, M. (2005). The job attitude differences among public and private school teachers in Albania. Unpublished Master Thesis. Middle East Technical University, Ankara.

3) Ivanevich, M.J. \& Donelly, H.J.(1975). Relation of organizational structure to Job Satisfaction, Anxiety-Stress, and Performance. Volumi 20. Johnson Graduate School of Management, Cornell University.

4) Spector, E. P. (1997). Job Satisfaction. Aplication, Assesment, Cause and Consequences. Cited in Buka. M (2005).

5) Kasimati, M. \& Manxhari, M. (2005). Sjellje Organizative, Second Edition, SHBLU.

6) www.bankofalbania.org

7) http://bkt.com.al/bktMain.aspx

8) http://business.time.com

9) www.aab.al

10) Argyle, M (1989). Do happy workers work harder? The effect of job satisfaction on work performance. Cited in Veenhoven.R

(1989).http://www2.eur.nl/fsw/research/veenhoven/Pub1980s/89a-C9-full.pdf, accessed [07.09.2014 